\title{
In Vitro Cytotoxicity and Apoptosis Induction in Human Cancer Cells by Culture Extract of an Endophytic Fusarium solani Strain Isolated from Datura metel L
}

Gini C Kuriakose ${ }^{1}$, Satpal Singh ${ }^{1}$, Pradumn K Rajvanshi ${ }^{1}$, William R Surin ${ }^{2}$ and Jayabaskaran C $^{1 *}$

${ }^{1}$ Department of Biochemistry, Indian Institute of Science, Bangalore-560012, India

${ }^{2}$ Department of Microbiology and Cell Biology, Indian Institute of Science, Bangalore-560012, India

\begin{abstract}
Objectives: Endophytic strains of many plants-particularly medicinal plants-produce a plethora of secondary metabolites, many of which are of immense pharmaceutical importance e.g. anticancer properties. Datura metel L., an important medicinal plant in use as a topical application to remove tumors apart from its other medicinal uses, has not been extensively explored for the potential of its endophytes for their pharmacological significance. The present study was thus initiated to investigate the anticancer effects of the organic extract of an endophytic fungus isolated from this plant.
\end{abstract}

Methods: We report the anticancer effects of an endophytic Fusarium solani fungal strain isolated from Datura metel L. as evaluated by its culture extract on five human cancer cell lines (HepG2, HeLa, MCF-7, OVCAR-3 and PC-3). The ethyl acetate (EtOAc) extract of three week grown fungal culture was tested for its cytotoxic activity on different cancer cell lines by MTT ([3-(4,5-dimethylthiazol-2-yl)-2,5-diphenyltetrazolium bromide] assay. The apoptosis-inducing activity and its effect on mitochondrial membrane potential were measured by flow cytometry using JC-1 dye. Nuclear DNA condensation was assessed by fluorescence microscopy using Hoechst 33342 stain. DNA fragmentation was visualized by gel electrophoresis.

Results: The ethyl acetate (EtOAc) fungal culture extract showed cytotoxic activity against all the tested human cancer cell lines, in particular against cervical cancer cells HeLa. Further, loss of mitochondrial membrane potential, DNA fragmentation and nuclear chromatin condensation strongly support the ability of organic extract to induce the cancer cell apoptosis though the mitochondrial pathway.

Conclusion: The results demonstrate that the Fusarium solani organic extract harbor potential anticancer lead compound(s) which inhibited the proliferation of various cancer cells by inducing cell apoptosis.

Keywords: Anticancer, Fusarium solani, Datura metel, Natural Products, Endophytes, Fermentation, Apoptosis

\section{Introduction}

Natural products have been playing a major role in the search for novel drugs for numerous illnesses including cancer [1-8]. The much celebrated and fortuitous discovery of the antibiotic penicillin from a fungus almost a century ago heralded an era of an intense research by chemists, biologists, publically funded government organizations and naturalists to explore compounds from nature for their pharmaceutical worth. Ever since, quite a few celebrated examples of these wonder molecules-challenging even the most adept chemists to their difficult chemical syntheses-have kept natural chemists, biologists and even industrial houses busy in search of new, simpler and easily available lead drug molecules from plants, microbes, etc. Most of the prominent producers of these natural products are found within three groups of organisms viz. plants, fungi and bacteria. Though utilizing the plant sources for obtaining these valuable molecules called secondary metabolites present many formidable challenges towards their sustained supply, e.g. seasonal variations and large-scale deforestation concerns, their microbial sources have generated substantial interest among academicians and commercial entities in the recent times. While plants and plant extracts have been playing an important role in traditional medicine for thousands of years, the discovery of and investigations on fungal and bacterial natural products had only been made possible with the development of natural sciences during the $20^{\text {th }}$ century. The secondary metabolites of microbial origin are well known as valuable supply of lead molecules in the quest for drug candidates against infectious diseases, cancer and many other illnesses [9].
Chemotherapy is a major treatment modality for cancer and some plants such as Catharanthus roseus, Podophyllum pultatum, Taxus brevifolia and Camptotheca acuminata have provided active principles $[10,11]$. The important plant-derived anticancer drugs

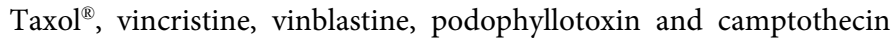
are still isolated from the source plants, thus bearing a high ecological cost. Additionally, severe side-effects invoked by most of the anticancer drugs are the major hurdles limiting their application and therapeutic success. Therefore, discovery of natural compounds with minimum or no toxicity in humans has been a major driver for anti-cancer natural product research of late. This has led to a need-based approach to find alternative drugs, which are highly effective at non-toxic doses, inexpensive and easily available to common man. Since all of the natural products would have gone through rigorous selection pressures in the wild natural conditions, their high specificities and effectiveness

*Corresponding author: Jayabaskaran C, Department of Biochemistry, Indian Institute of Science, Bangalore-560012, India, Tel: +91-80-22932482; Fax: +91-8023600814; E-mail: cjb@biochem.iisc.ernet.in

Received March 06, 2014; Accepted March 24, 2014; Published March 27, 2014

Citation: Kuriakose GC, Singh S, Rajvanshi PK, Surin WR, Jayabaskaran C (2014) In Vitro Cytotoxicity and Apoptosis Induction in Human Cancer Cells by Culture Extract of an Endophytic Fusarium solani Strain Isolated from Datura metel L. Pharm Anal Acta 5: 293. doi: 10.4172/2153-2435.1000293

Copyright: $\odot 2014$ Kuriakose GC, et al. This is an open-access article distributed under the terms of the Creative Commons Attribution License, which permits unrestricted use, distribution, and reproduction in any medium, provided the original author and source are credited. 
Citation: Kuriakose GC, Singh S, Rajvanshi PK, Surin WR, Jayabaskaran C (2014) In Vitro Cytotoxicity and Apoptosis Induction in Human Cancer Cells by Culture Extract of an Endophytic Fusarium solani Strain Isolated from Datura metel L. Pharm Anal Acta 5: 293. doi: 10.4172/21532435.1000293

Page 2 of 8

against their animal physiological targets seems rather better than the randomly selected synthetic compounds through high-throughput drug screening studies.

The combination of all these factors has greatly facilitated efforts in the search for more effective and novel secondary metabolites as anticancer lead molecules for some time now. The plant extracts have traditionally been screened for such discoveries, however many of the endophytic fungi have also been shown to possess associated plant active principles such as Taxol ${ }^{\circledR}$, vincristine, podophyllotoxin, camptothecin, etc. [12-15]. Moreover, these endophytes have been shown to be a versatile source of many new biologically active chemical structures [16]. Many endophytic fungi are added every year to this ever growing list of biologically relevant strains producing valuable drug candidates which is a testimony to the fact that only a tiny fraction of an estimated one million endophytic fungal species has been cultured and screened for their bioactivities [17].

Datura metel L. (Thorn apple), belonging to the family Solanaceae is one of the important medicinal plants found in India. This tropane alkaloids-producing plant, has empirically been reported to be used as traditional medicine for narcotic, aphrodisia, febrifuge, anthelmintic and topically applied to remove tumors by local society [18]. However, there is no information about endophytes of Datura metel competent to exhibit biological activities especially involving cancer. The present investigation was thus initiated to screen the endophytic fungi of this plant for the strains demonstrating in vitro anticancer properties against human cancer cell lines. An endophytic fungus Fusarium solani isolated from $D$. metel has been shown in this study to indeed possess the in vitro human cytotoxic activity by prohibiting the growth of cancer cells and inducing apoptosis.

\section{Materials and Methods}

\section{Reagents and materials}

Sodium dodecyl sulfate (SDS), tris- $\mathrm{HCl}$, ethylenediaminetetraacetic acid (EDTA), acridine orange, ethidium bromide, fetal bovine serum, propidium iodide, RNase A, proteinase $\mathrm{K}, 2,4$-DNP were obtained from Sigma Chemicals Company (San Diego, USA). DCFH-DA and Annexin-V stains were obtained from Life Technologies (USA), $\mathrm{H}_{2} \mathrm{O}_{2}$ was purchased from SRL chemicals (Mumbai, India). All other reagents were of analytical grade. Out of 18 endophytic Datura metel fungal isolates (data not shown) only one named F. solani was selected for the present study because of relatively high anticancer activity of its extract on HeLa cells during preliminary screening of different fungal culture extracts for anticancer activity by MTT assay (data not shown). The fungus was identified by ITS-rDNA DNA sequencing using a pair of primers ITS1 (sequence: 5'-TCC GTA GGT GAA CCT GCG G-3') and ITS4 (5'-TCC TCC GCT TAT TGA TAT GC-3 [19]. The corresponding sequence of each endophytic fungus was then used for similarity analysis using Blast $\mathrm{N}$ algorithm against the public database at the National Center for Biotechnology Information (NCBI; http:// www.ncbi.nlm.nih.gov and GenBank accession number JN600625).

\section{Fusarium solani fermentation conditions and preparation of the fungal organic extract}

Using a primary inoculum, the fungal culture was grown in 500 $\mathrm{mL}$ of potato dextrose liquid medium in $2 \mathrm{~L}$ Erlenmeyer flasks at $25^{\circ} \mathrm{C}$ in the dark under static conditions. After 21 days, the entire culture mixture was blended well using a commercial blender and extracted twice with an equal volume of ethyl acetate (EtOAc). The organic phase was separated and evaporated to dryness using a rotary vacuum evaporator at $40^{\circ} \mathrm{C}$. The residue was weighted, dissolved in $1 \mathrm{~mL}$ methanol and kept at $4^{\circ} \mathrm{C}$ until use.

\section{Human cancer cell lines and culture conditions}

A total of five human cancer cell lines namely HepG2 (Human hepatocarcinoma), HeLa (human cervical carcinoma), MCF-7 (human breast adenocarcinoma), OVCAR-3 (human ovarian carcinoma) and PC-3 (human prostate cancer) were used for these experiments. These were grown in DMEM supplemented with $10 \% \mathrm{FBS}$ in a $5 \% \mathrm{CO}$ incubator at $37^{\circ} \mathrm{C}$. Penicillin $(100 \mathrm{IU} / \mathrm{mL})$ and streptomycin $(100 \mu \mathrm{g} /$ $\mathrm{mL}$ ) were added in the DMEM medium to prevent bacterial growth.

\section{Assessment of cytotoxicity by MTT assay}

Cytotoxic effect of the fungal organic extract was determined as described earlier [20]. Cells were grown in micro titer 96 well flat bottom plates in a final volume of $100 \mu \mathrm{L}$ culture medium per well and incubated for at $37^{\circ} \mathrm{C}$ and $5 \% \mathrm{CO}_{2}$ for $24 \mathrm{~h}$. At the end of the 24 $\mathrm{h}$ incubation upon formation of a partial monolayer, the supernatant was flicked off, cells were washed once and fungal organic extract (2.5$50 \mu \mathrm{g} / \mathrm{mL}$ ) was added into the respectively labeled wells. After $24 \mathrm{~h}$ incubation period, $10 \mu \mathrm{L}$ of $5 \mathrm{mg} / \mathrm{mL}$ MTT solution in PBS was added to each well and incubated for $2 \mathrm{~h}$. Thereafter, medium was removed and $100 \mu \mathrm{L}$ of DMSO was added to all wells to dissolve the formazan crystals. Plates were read at $570 \mathrm{~nm}$ using a microplate reader and results were expressed as viability percentage against the untreated control cells ( $100 \%$ of viability). Triplicate wells were assayed for each condition and standard deviations were determined.

\section{Cell cycle analysis}

Flow cytometry was performed to determine all cell cycle kinetics and apoptotic populations [21]. Approximately, $2.5 \times 10^{5}$ cells of different cell lines HeLa, HepG2, OVCAR-3, MCF-7 or PC-3 were cultured in 24 well plates in $0.5 \mathrm{~mL}$ of medium. Adherent cells were allowed to adhere overnight. The cells were treated with different concentrations of the fungal organic extract $(2.5-50 \mu \mathrm{g} / \mathrm{mL})$ in DMEM medium supplemented with $10 \%(\mathrm{v} / \mathrm{v})$ foetal bovine serum (FBS) for $24 \mathrm{~h}$. The cells were harvested, washed twice with ice-cold PBS, fixed in $70 \%(\mathrm{v} / \mathrm{v})$ ice-cold ethanol for $30 \mathrm{~min}$ and stained with $20 \mu \mathrm{g} / \mathrm{mL}$ propidium iodide containing, $100 \mu \mathrm{g} / \mathrm{mL}$ RNaseA, $1 \%(\mathrm{v} / \mathrm{v})$ Triton $\mathrm{X}-100$ in PBS for $60 \mathrm{~min}$ at $37^{\circ} \mathrm{C}$ followed by flow cytometry using FACS Calibur (Becton Dickinson, USA) and analyzed using CellQuest ${ }^{\mathrm{TM}}$ Pro software. Apoptotic cell populations were quantified by the sub- $\mathrm{G}_{1}$ peak using CellQuest ${ }^{\mathrm{TM}}$ Pro software.

\section{Determination of the mitochondrial membrane potential}

The mitochondrial membrane potential (MMP or $\Delta \Psi \mathrm{m}$ ) was measured using the potentiometric dye JC-1 as reported [22]. Briefly, $2.5 \times 10^{5}$ cells per well were incubated with different concentrations of fungal organic extract for $24 \mathrm{~h}$ in serum containing medium in 24 well plates and stained with $2.5 \mu \mathrm{g} / \mathrm{mL}$ of JC- 1 dye at $37^{\circ} \mathrm{C}$ for $15 \mathrm{~min}$ in the $\mathrm{CO}_{2}$ incubator. Cells were then washed with ice-cold PBS containing $2 \%(\mathrm{v} / \mathrm{v})$ foetal bovine serum (FBS) and analyzed immediately by flow cytometry using FACS Calibur (Becton Dickinson, USA) at an excitation/emission wavelength of $488 \mathrm{~nm}$ and 530/30, 585/42 nm, respectively and analyzed by CellQuest ${ }^{\mathrm{TM}}$ Pro software. The emission of JC-1 monomers peaks at $530 \mathrm{~nm}$ (FL-1 channel- green fluorescence) while that of J-aggregates peaks at $590 \mathrm{~nm}$ (FL-2 channel-red fluorescence). 2,4-Dinitrophenol (2,4-DNP) treated cells served as the positive control and untreated cells were taken as the negative control. 
Citation: Kuriakose GC, Singh S, Rajvanshi PK, Surin WR, Jayabaskaran C (2014) In Vitro Cytotoxicity and Apoptosis Induction in Human Cancer Cells by Culture Extract of an Endophytic Fusarium solani Strain Isolated from Datura metel L. Pharm Anal Acta 5: 293. doi: 10.4172/21532435.1000293

Page 3 of 8

\section{Qualitative analysis of changes in nuclear morphology}

Hoechst $33342(1 \mathrm{mg} / \mathrm{mL}$ in PBS) was used to determine the changes in chromatin organization after treatment with the fungal organic extract as per Lee and Shacter (1999) [23]. Approximately $5 \times 10^{4} \mathrm{HeLa}$ cells in $300 \mu \mathrm{L}$ of $10 \%$ DMEM were placed on round cover slips ( $12 \mathrm{~mm}$ ) inside 24 well plates. After overnight adherence cells were incubated with different concentrations of the fungal organic extract. Cells were then fixed with 3.7\% paraformaldehyde and permeabilized with $0.1 \%$ Triton X-100. The cells were rinsed twice in PBS and stained with Hoechst 33342. After the PBS washes, coverslips were mounted and observed at 10x magnification under a fluorescence microscope using 360/40 $\mathrm{nm}$ excitation and 460/50 $\mathrm{nm}$ emission filters.

\section{AnnexinV-FITC/proidium iodide dual stain assay for} quantification of apoptotic cells

The AnnexinV-FITC/ proidium iodide procedure followed was essentially as per the manufacturer. Briefly, $2.5 \times 10^{5}$ cells per well were incubated in serum containing medium with different concentrations $(5,10$ and $25 \mu \mathrm{g} / \mathrm{mL})$ of fungal organic extract for $24 \mathrm{~h}$ in a $\mathrm{CO}_{2}$ incubator in 24 well plates. The cells were subsequently stained with recommended concentrations of AnnexinV-FITC stain with or without PI stain in a buffer and analyzed by flow cytometry using FACS Calibur (Becton Dickinson, USA) using excitation $\left(\lambda_{\mathrm{ex}}\right) / \mathrm{emission}\left(\lambda_{\mathrm{em}}\right)$ of $488 / 520 \mathrm{~nm}$ for AnnexinV-FITC and 540/630 nm for proidium iodide and analyzed by CellQuest ${ }^{\mathrm{TM}}$ Pro software. Untreated cells were used as the negative control in four different ways as unstained cells, cells stained with AnnexinV-FITC alone, cells stained with proidium iodide alone and cells stained with both AnnexinV-FITC and proidium iodide.

\section{Measurement of DNA fragmentation}

DNA fragmentation was measured essentially as described by Gong et al. (1994) [24]. HeLa cells $\left(3-4 \times 10^{6} / \mathrm{mL}\right)$ were cultured in $10 \%$ FBSDMEM medium. After incubation for $24 \mathrm{~h}$ with different concentrations of the fungal organic extract, cells were collected by centrifugation at $1000 \times g$ at ambient temperature for $5 \mathrm{~min}$, washed with $1 \mathrm{~mL}$ of $50 \mathrm{mM}$ PBS and fixed in $70 \%$ chilled ethanol for overnight. After fixation, the cells were centrifuged at $1000 \times \mathrm{g}$ for $5 \mathrm{~min}$ and re-suspended in $40 \mu \mathrm{L}$ of phosphate-citrate buffer (192 parts of $0.2 \mathrm{M} \mathrm{Na}_{2} \mathrm{HPO}_{4}$ and 8 parts of $0.1 \mathrm{M}$ of citric acid, $\mathrm{pH} 7.8$ ) at ambient temperature for $30 \mathrm{~min}$. After centrifugation at $1000 \times \mathrm{g}$ for $5 \mathrm{~min}$, the supernatant was concentrated in a Speed Vac concentrator for $15 \mathrm{~min}$. To this $3 \mu \mathrm{L}$ aliquot of $0.25 \%$ Nonidet P-40 and $3 \mu \mathrm{g}$ of RNase A were added and incubated for 30 min at $37^{\circ} \mathrm{C}$. After addition of $3 \mu \mathrm{g}$ of proteinase $\mathrm{K}$ the incubation was continued for $30 \mathrm{~min}$ at $37^{\circ} \mathrm{C}$. To this $12 \mu \mathrm{L}$ of $6 \mathrm{x}$ DNA loading buffer $(0.25 \%$ bromophenol blue, $0.25 \%$ xylene cyanol, $30 \%$ glycerol, $10 \mathrm{mM}$ EDTA as final concentrations) was added and the mixture was electrophoresed on a $0.8 \%$ agarose gel at $2 \mathrm{~V} / \mathrm{cm}$ for $16 \mathrm{~h}$. $100 \mathrm{bp}$ DNA marker was used as reference. The DNA in the gel was visualized under UV light after staining with ethidium bromide $(5 \mu \mathrm{g} / \mathrm{mL})$.

\section{Results}

Cytotoxic effect of crude Fusarium solani organic extract on different cancer cells

Anticancer activity of the organic extract of Datura metel endophytic fungus $F$. solani on various cancer cell lines (HeLa, HepG2, OVCAR-3, MCF-7 and PC-3) at different concentrations was tested. The results showed variable effect across different cell types as tested by MTT assay (Figure 1). Dose dependent inhibitions in all cell lines

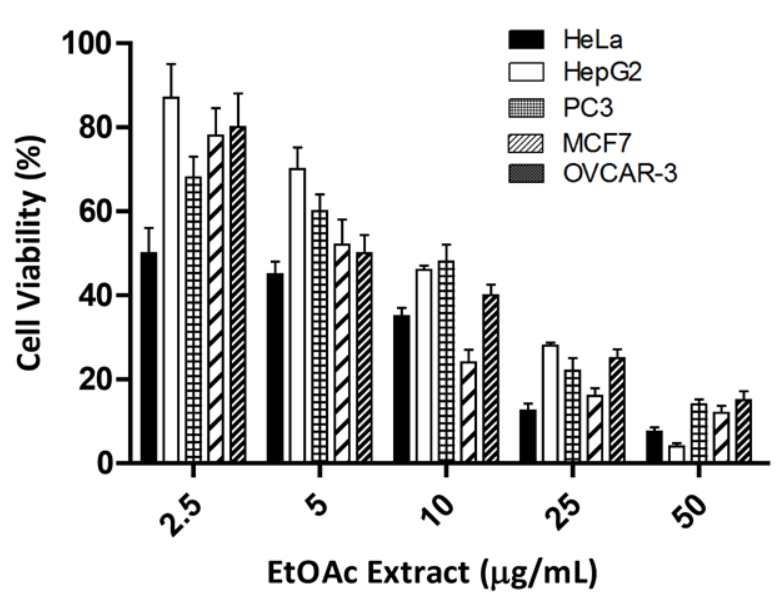

Figure 1: Cytotoxic activity of $F$. solani organic extract on different human cancer cells, HeLa, HepG2, OVCAR-3, MCF-7 or PC3. Cells were cultured and treated with various concentrations of the extract $(2.5-50 \mu \mathrm{g} /$ $\mathrm{mL}$ ) for $24 \mathrm{~h}$ and percentage viability of surviving cells was measured as described in "Materials and Methods".

were observed upon treatment with the fungal organic extract. The crude fungal organic extract at $2.5 \mu \mathrm{g} / \mathrm{mL}$ inhibited growth by $50 \%$, $30 \%, 20 \%$ and $10 \%$ in HeLa, PC-3, MCF-7/OVCAR-3 and HepG 2 cell lines, respectively whereas at $25 \mu \mathrm{g} / \mathrm{mL}$ and $50 \mu \mathrm{g} / \mathrm{mL}$ almost complete cessation of cell growth was observed in all cell lines (Figure 1). This suggests that the fungal organic extract is most effective against HeLa cell lines. Therefore, HeLa cells were selected for further studies to analyze various processes involved in the fungal organic extractmediated cell death.

Effect of $F$. solani organic extract on cell cycle DNA content of HeLa cells

HeLa cells were treated with various concentrations of extract and stained with propidium iodide to determine the proportion of cells undergoing apoptosis or cell death as analyzed by flow cytometry. These studies showed the distribution of cell population across various phases of cell cycle (Sub- $G_{0} / G_{1}, G_{0} / G_{1}, S$ and $G_{2} / M$ ). We observed 77 $98 \%$ cells undergoing cell death or apoptosis in sub-Go/G1 region following treatment with $F$. solani organic extract $(2.5 \mu \mathrm{g} / \mathrm{mL}$ to 50 $\mu \mathrm{g} / \mathrm{mL}$ ) while only $8.3 \%$ of the control cells in Sub- $G_{0} / G_{1}$ phase were observed (Figure 2). These results show that organic extract of $F$. solani induces cell death by accumulation of cells in Sub- $\mathrm{G}_{1}$ phase. However, to ascertain whether the cell death happened through apoptosis or necrotic events (as both necrotic and apoptotic cells take up propidium iodide and show up in the Sub-G0/G1 region), further experiments were conducted.

\section{Mitochondrial membrane depolarization by $F$. solani organic extract}

F. solani organic extract was analyzed for its effect on mitochondrial membrane depolarization. Mitochondrial membrane depolarization is an early event of apoptosis. Chemotherapeutic agents usually induce apoptosis via mitochondrial pathway [22]. As examined by using the fluorescent dye JC-1, the decreased mitochondrial membrane potential $(\Delta \Psi \mathrm{m})$ was observed in HeLa cells in a dose-dependent manner (Figure 3). These results suggest that apoptosis of Hela cells by the fungal organic extract is associated with changes in mitochondrial membrane potential. Loss of $\Delta \Psi \mathrm{m}$ causes release of cytochrome $\mathrm{c}$ and subsequent 
Citation: Kuriakose GC, Singh S, Rajvanshi PK, Surin WR, Jayabaskaran C (2014) In Vitro Cytotoxicity and Apoptosis Induction in Human Cancer Cells by Culture Extract of an Endophytic Fusarium solani Strain Isolated from Datura metel L. Pharm Anal Acta 5: 293. doi: 10.4172/21532435.1000293
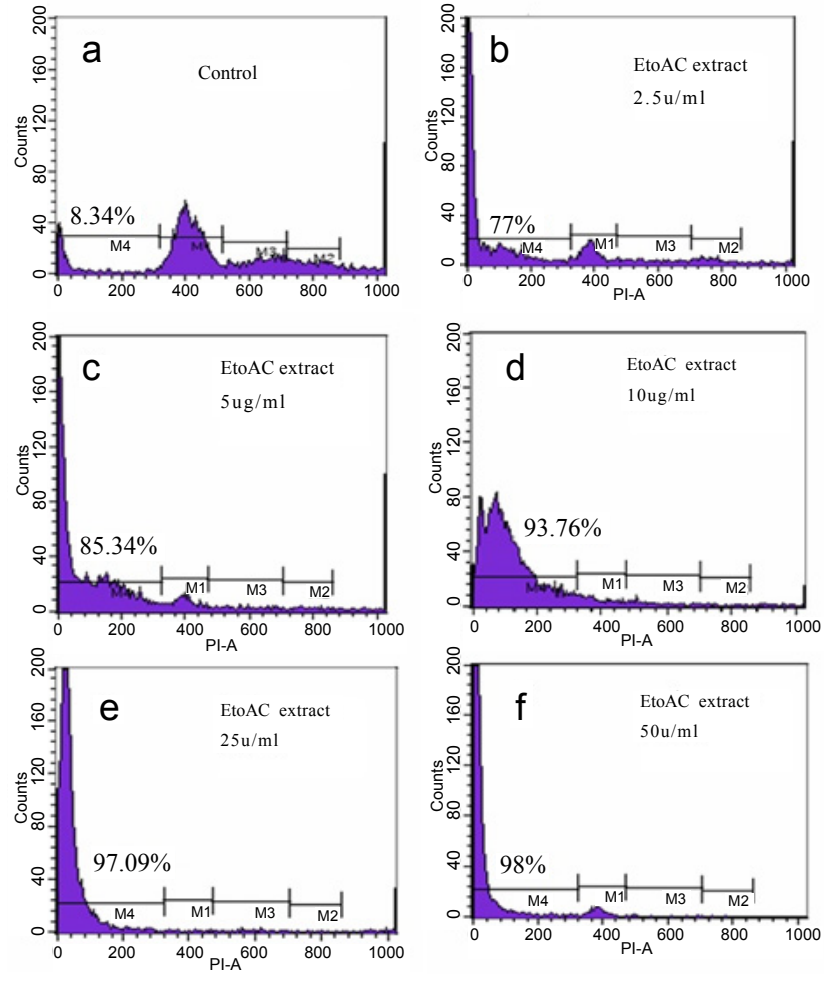

DNA Content

Figure 2: The effect of $F$. solani organic extract on cell cycle progression in HeLa cells. HeLa cells were treated with various concentrations of $F$. solani organic extract $(2.5-50 \mu \mathrm{g} / \mathrm{mL})$ for $24 \mathrm{~h}$. Cells were stained with PI and analyzed using BD FACScan flow cytometer (Materials and Methods). One of the three independent experiments is shown. The percentage of hypodiploid cells (sub G-peak) was calculated on the basis of the respective histograms.

activation of caspase 9 which eventually brings about apoptosis by downstream caspases [25]. This observation shows that extract might induce apoptotic cell death via mitochondrial pathway.

\section{Microscopic characterization of nuclear morphology upon fungal organic extract treatment}

To further confirm the apoptosis-mediated cell death induced by F. solani organic extract, HeLa cell nuclear morphology was assessed by fluorescence microscopy. The cells after treatment with different concentrations of the fungal organic extract were labeled with Hoechst 33342 to observe the chromatin condensation. Fungal organic extracttreated HeLa cells exhibited physiological changes in the nuclear chromatin, such as cell shrinkage, chromatin condensation and cell nuclear fragmentation, which are all hallmarks of apoptosis (Figure 4A-4D) while untreated cells displayed intact nuclear architecture (Figure 4A). These results suggest the possible effect of the fungal organic extract to mediate cell death in HeLa cells through apoptotic process.

\section{Quantification of apoptotic cells as a measure of membrane changes by AnnexinV-FITC}

As described in Materials and Methods, after treatment with the increasing concentrations of the fungal organic extract for $24 \mathrm{~h}$, the HeLa cells were stained with the AnnexinV-FITC with or without proidium iodide. The FACS can analysis on the control untreated cells revealed that the untreated cells were primarily AnnexinV-FITC and proidium iodide negative indicating that they were viable and not undergoing apoptosis. Upon treatment with different concentrations $(5,10$ and $25 \mu \mathrm{g} / \mathrm{mL})$ of the fungal organic extract, however the cells
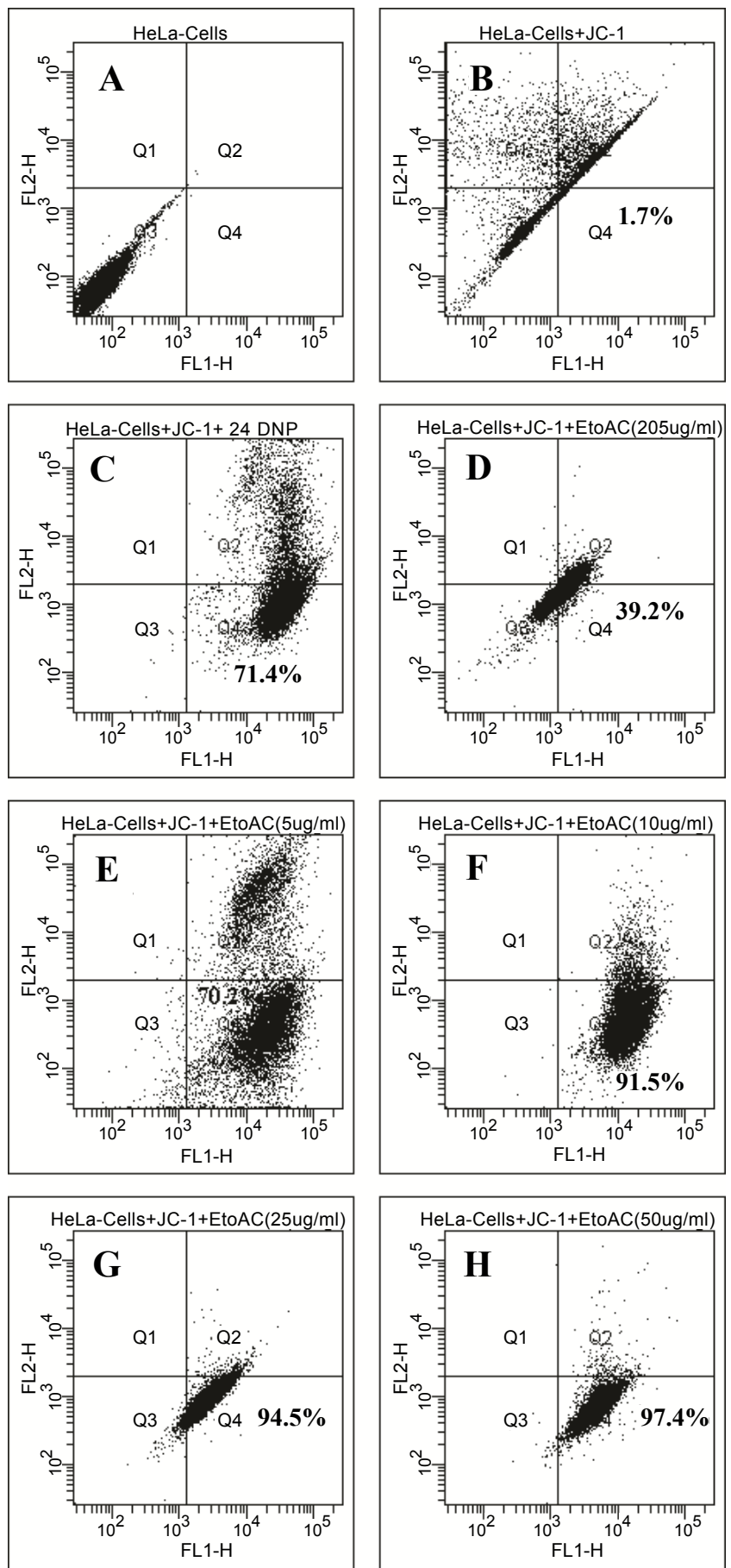

Figure 3: Induction of loss of mitochondrial membrane potential (MMP or $\Delta \Psi \mathrm{m}$ ) by $F$. solani organic extract. HeLa cells were treated for $24 \mathrm{~h}$ with $2.5 \mu \mathrm{g} / \mathrm{mL}$ (D), $5 \mu \mathrm{g} / \mathrm{mL}(\mathrm{E}), 10 \mu \mathrm{g} / \mathrm{mL}(\mathrm{F}), 25 \mu \mathrm{g} / \mathrm{mL}(\mathrm{G})$ and $50 \mu \mathrm{g} / \mathrm{mL}(\mathrm{H})$ of $F$. solani organic extract or the positive control agent 2,4 DNP (C). A and B represent experimental controls of untreated cells alone and untreated cells $+\mathrm{JC}-1$ stain, respectively. $\Delta \Psi_{\mathrm{m}}$ was measured by BD FACScan flow cytometer as described under "Materials and Methods". One of the three independent experiments is shown. 
Citation: Kuriakose GC, Singh S, Rajvanshi PK, Surin WR, Jayabaskaran C (2014) In Vitro Cytotoxicity and Apoptosis Induction in Human Cancer Cells by Culture Extract of an Endophytic Fusarium solani Strain Isolated from Datura metel L. Pharm Anal Acta 5: 293. doi: 10.4172/21532435.1000293
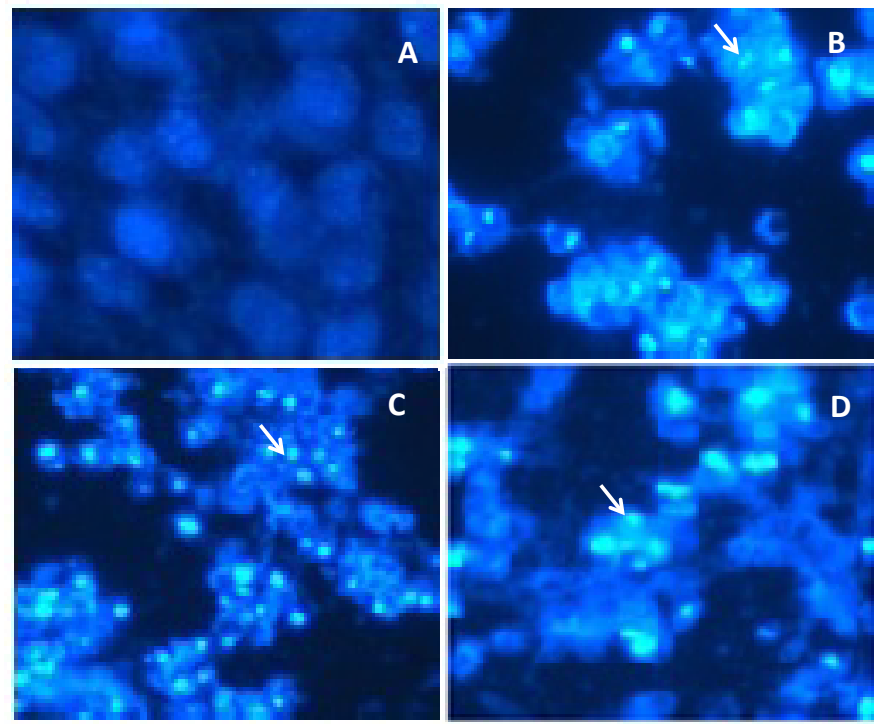

Figure 4: Induction of apoptotic nuclear morphology of HeLa cells treated with F. solani organic extract. Nuclear morphology was analyzed by fluorescence microscopy upon staining with Hoechst 33342 . HeLa cells were cultured in the absence (A) or presence of $2.5 \mu \mathrm{g} / \mathrm{mL}$ (B), $5 \mu \mathrm{g} / \mathrm{mL}$ (C) and $10 \mu \mathrm{g} / \mathrm{mL}$ (D) of $F$. solani organic extract for $24 \mathrm{~h}$, stained with Hoechst 33342 and analysed as described in "Materials and Methods". Arrows indicate the nuclear chromatin condensation foci.
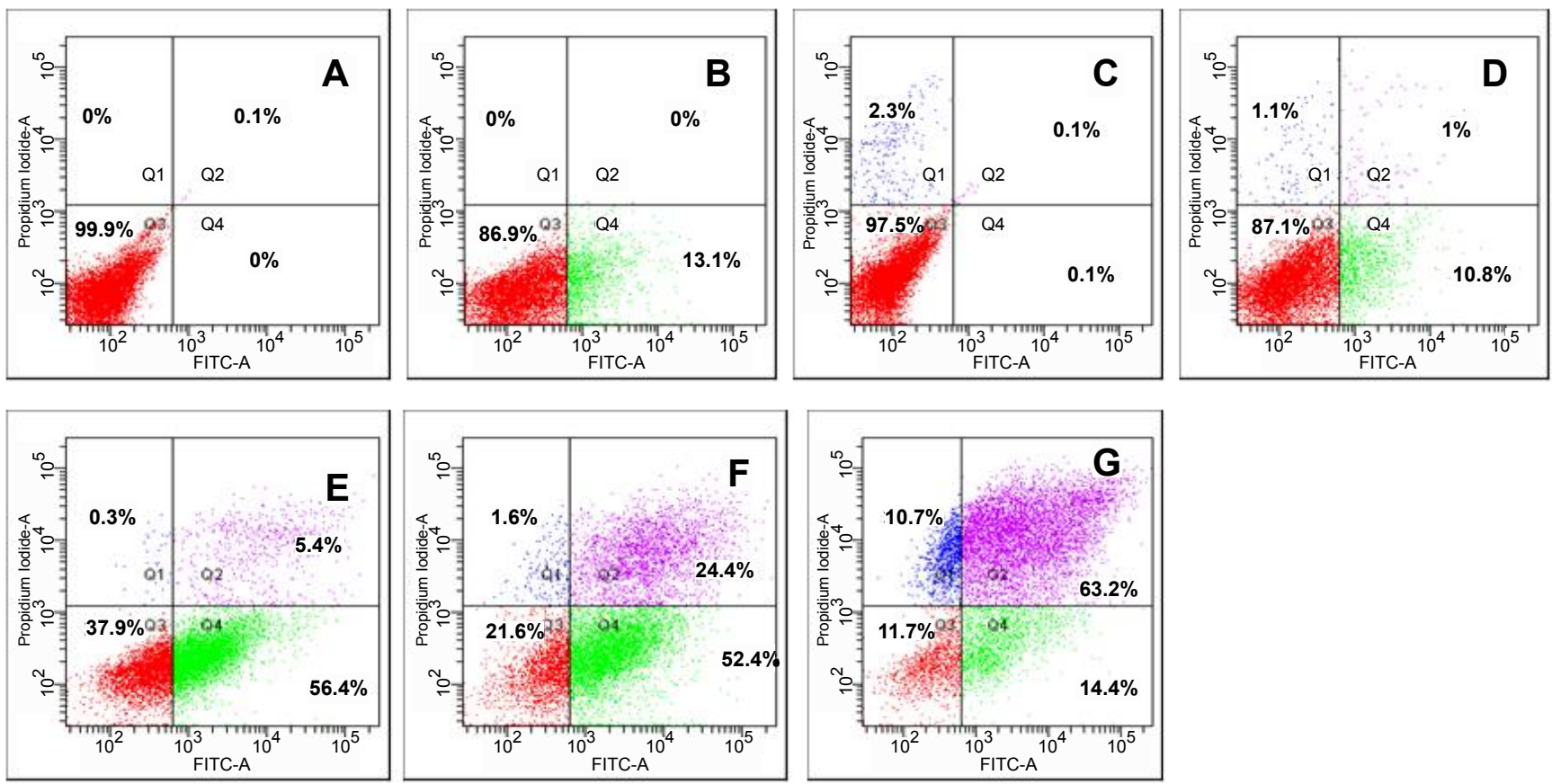

Figure 5: Induction of apoptosis by $F$. solani organic extract and confirmation by AnnexinV-FITC/PI dual staining. HeLa cells were treated with $5 \mu \mathrm{g} / \mathrm{mL}$ (E), $10 \mu \mathrm{g} /$ $\mathrm{mL}(\mathrm{F})$ and $25 \mu \mathrm{g} / \mathrm{mL}(\mathrm{G})$ of $F$. solani organic extract for $24 \mathrm{~h}$ and analysed using BD FACScan flow cytometer as described in "Materials and Methods". A, B, C and $D$ represent experiment controls of untreated cells alone, untreated cells+AnnexinV-FITC, untreated cells+PI and untreated cells+ AnnexinV-FITC+PI, respectively. Normal healthy, early apoptotic, late apoptotic and dead/necrotic cell populations are shown as percentage of total cells in the quadrants Q3, Q4, Q2 and Q1, respectively.

started showing distribution into four different populations as revealed by the FACScan analysis: healthy cells (AnnexinV-FITC and proidium iodide negative, Q3), cells undergoing early apoptosis (AnnexinVFITC positive and proidium iodide negative, Q4), cells exhibiting late apoptosis or necrosis (AnnexinV-FITC and proidium iodide positive, Q2) and a dead cell population (proidium iodide positive, Q1). It is interesting to note that at low concentration $(5 \mu \mathrm{g} / \mathrm{mL})$, the majority of cells exhibited an early apoptotic phenotype (56.4\%) with only $5.4 \%$ in the late apoptosis/necrotic phase (Figure 5); however, as the concentration increased, more cells started appearing in the quadrant 2 in a dose-dependent manner $(24.4$ and $63.2 \%$ for 10 and $25 \mu \mathrm{g} / \mathrm{mL}$, respectively), which is indicative of late apoptotic or necrotic population 
Citation: Kuriakose GC, Singh S, Rajvanshi PK, Surin WR, Jayabaskaran C (2014) In Vitro Cytotoxicity and Apoptosis Induction in Human Cancer Cells by Culture Extract of an Endophytic Fusarium solani Strain Isolated from Datura metel L. Pharm Anal Acta 5: 293. doi: 10.4172/21532435.1000293

(Figure 5). This might indicate cross-talk of the active principle in the fungal organic extract with different cell death pathways at higher concentrations or synergistic effect of different components of the fungal organic extract.

\section{Nuclear DNA fragmentation of HeLa cells by F. solani organic extract}

Genomic DNA fragmentation is one of the most important hallmarks of the apoptotic cells [26]. HeLa cells treated with different concentration of the fungal organic extract for $24 \mathrm{~h}$ showed internucleosomal DNA fragments in the form of DNA ladder mimicking the typical DNA fragmentation pattern in a dose dependent manner (Figure 6). The high degree of DNA fragmentation without appearance of nonspecific DNA degradation which would be otherwise seen as DNA smear is a clear indication of apoptotic inducing ability of this extract. This shows that the given F. solani organic extract has potent apoptotic induction potential in these cells as early as $24 \mathrm{~h}$ as shown.

\section{Discussion}

Throughout human history and especially in the past century, natural products have virtually remained undisputed leaders among the various therapeutic tools humans have employed against many diseases including cancer [1-8]. Endophytic microorganism especially fungi are potential source of known and novel natural products. They have been shown to produce many known as well as unknown new chemical compounds called secondary metabolites which have remained the subject of numerous research groups and organizations across the world [27]. The large-scale and still untapped biodiversity of earth further encourages such efforts. Moreover, the ever increasing demand of life-saving and potent drugs in the face of a less successful traditional industrial drug-discovery pipeline has virtually brought these enigmatic microorganisms to unprecedented biomedical prominence. In the present study, an endophytic fungus Fusarium solani isolated from the medicinal plant Datura metel was investigated for evaluating its potential of in vitro halting the growth of various human cancer cells. This endophytic fungus was chosen for detailed 2.5 10

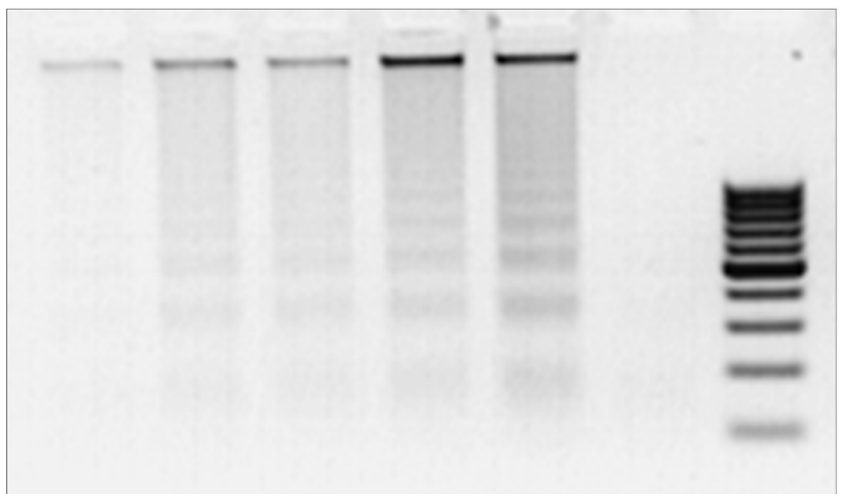

Figure 6: Aoptotic DNA fragmentation in HeLa cells by F. solani organic extract. Untreated "C" HeLa cells or those treated with indicated concentrations (in units of $\mu \mathrm{g} / \mathrm{mL}$ ) of $F$. solani organic extract for $24 \mathrm{~h}$ were harvested for DNA extraction as described in "Materials and Methods". Extracted DNAs were analyzed by electrophoresis on $0.8 \%$ agarose gel. The gel was stained with ethidium bromide and viewed under a UV transilluminator. Fragmented internucleosomal DNA appears as ladder. "M" represents 100 bp DNA marker with a sharp band at $500 \mathrm{bp}$. anti-proliferative studies because of the relatively high in vitro toxicity of its organic extract as determined by MTT assay in HeLa cells (data not shown). We tested the organic extract of this fungal culture against a number of human cancer cell lines. The results demonstrated that the fungal organic extract exhibited potent cytotoxic activity against several cell lines in a dose dependent manner. The cytotoxic effect was found to be more pronounced in HeLa (human cervical carcinoma) cells followed by OVCAR-3 (human ovarian carcinoma), MCF-7 (human breast adenocarcinoma), PC-3 (human prostate cancer) and HepG2 (Human hepatocarcinoma) (Figure 1).

The ability of the endophytic fungi as sources of many celebrated and novel lead drug compounds has been well documented [13$15,27,28]$. Stierle et al. [12] demonstrated Taxol ${ }^{\mathbb{}}$-producing ability of an endophytic fungus of Yew tree which was shown to be independently capable of its biosynthesis. Subsequently, several endophytic fungi that produce Taxol ${ }^{\circledR}$ had been isolated from many different plants $[29,30]$. Similar to $\mathrm{Taxol}^{\circledR}$, podophyllotoxin, camptothecin and vincristine/ vinblastine have also been reported to be produced by endophytic fungi isolated from the associated host plants [13-15]. The ecological cost of plant destruction to obtain large quantities of the clinically used anticancer drugs limits the drug supply to the steadily increasing pharmaceutical demand which cannot be met in the foreseeable future in the absence of alternative sources [13]. Therefore, searching for novel and effective anticancer drugs is imperative. This can be achieved by screening new molecules from endophytic fungi for anticancer activity which may be effective at non-toxic dosage levels and prove cost effective and time saving when compared to the plant sources.

Inhibition of proliferation and/or induction of apoptosis in cancer cells is the most important characteristic of many anti-cancer agents [31]. In the present work, using a number of techniques to study such parameters as nuclear DNA cleavage (sub-diploid peak) by propidium iodide (PI) stain, loss of mitochondrial membrane potential by JC-1 stain, chromatin condensation by Hoechst 33342 stain and DNA fragmentation (DNA ladder) by gel electrophoresis, it was found that the $F$. solani organic extract induced apoptosis possibly by the mitochondrial pathway in HeLa cells. To study if any stage of the cell cycle was blocked by the fungal extract, PI staining was employed in the flow cytometry analysis. A distinctive appearance of the pre- $\mathrm{G}_{0} / \mathrm{G}_{1}$ cell population in HeLa cells was observed after treatment with fungal organic extract indicating that the extract indeed induced apoptosis (Figure 2). Moreover, using the potentiometric stain JC1 , a loss of mitochondrial membrane potential (MMP) $(\Delta \psi \mathrm{m})$ was observed after treatment with the fungal organic extract for $24 \mathrm{~h}$ (Figure 3). The increase in the low $\Delta \psi \mathrm{m}$ population of HeLa cells was observed in a dose dependent manner, thereby confirming the specific effect of the fungal extract (Figure 3 ). This suggests the possibility that the fungal organic extract-induced apoptosis possibly occurs by the mitochondrial pathway. Mitochondrial permeability transition has been shown to be an important step in the induction of cellular apoptosis. During this process, the electrochemical gradient across the mitochondrial membrane collapses. The collapse is thought to occur through formation of pores in the mitochondria by dimerized Bax or activated Bid, Bak or Bad proteins [32]. Activation of these proapoptotic proteins is accompanied by the release of cytochrome $\mathrm{c}$ into the cytoplasm $[25,31]$. Though at present these parameters have not been investigated for this extract, one might attempt such studies on the fungal organic extract-treated cells once the active principle in the extracts is purified. The onset of- and execution of apoptosis cascade in the cells is a tightly regulated process where the neighboring healthy cells in the tissues are spared of the potential adverse effects $[31,33]$. 
Citation: Kuriakose GC, Singh S, Rajvanshi PK, Surin WR, Jayabaskaran C (2014) In Vitro Cytotoxicity and Apoptosis Induction in Human Cancer Cells by Culture Extract of an Endophytic Fusarium solani Strain Isolated from Datura metel L. Pharm Anal Acta 5: 293. doi: 10.4172/21532435.1000293

Page 7 of 8

This includes many steps such as shrinkage of cell and the nucleus, nuclear chromatin condensation and membrane blebbing to produce apoptotic bodies to be subsequently engulfed by macrophages which ensure the safety of nearby normal cells. In the studies performed on the HeLa cells treated with F. solani organic extract to study some of these events, it was found that the extract indeed induced the apoptotic features such as chromatin condensation (Figure 4). Flipping of the phopholipid phosphatidylserine (PS) from the inner leaflet to the outer one of the cell membrane lipid bilayer is yet another hallmark feature of the cells undergoing apoptosis [31,34]. This PS molecular exposure is easily picked up by the PS binding dye, Annexin-V which is usually conjugated to a fluorophore to score the apoptotic cells either flow cytometrically or microscopically. When the HeLa cells were challenged with the fungal organic extract, such a phenotype was indeed observed in the flow cytomer analysis of the treated cells which was significantly higher than the basal level phenotype observed in the control cells (Figure 5). At higher extract concentrations the cells, however exhibited late apoptosis or necrotic death at a higher rate (Figure 5). This may imply that there might be some cross talk of the active principle(s) with other cell death pathways or there are more than one bio-active molecules with different cell death mechanisms. One of the distinctive features of apoptosis is the fragmentation of internucleosomal DNA into multimers of approximately $200 \mathrm{bp}$ due to the activation of endonuclease activated by caspases $[31,33,35]$. This step is usually believed to be the terminal step in the apoptosis cascade. Our results provide clear evidence on the ability of fungal organic extract to induce genomic DNA fragmentation resulting in the typical DNA ladder pattern as seen in HeLa cells (Figure 6).

Clinically used anticancer drugs generally induce complex responses in cancer cells. Studying the mechanisms underlying these responses is important in order to understand how drugs should be optimally used and why tumor cells become resistant to them. Investigations on the molecular mechanism of Taxol ${ }^{\circledR}$ action in various cancer cell lines, for example, revealed that it binds to the tubulin and stabilizes microtubules and therefore arrests cell-cycle. This cell cycle arrest induces apoptosis in most of the cancer cell types. Caspases trigger apoptosis through a well-orchestrated cascade [31,33]. Various forms of cancers require multiple approaches for their treatment, which opens a wide field of research in the discovery of new anticancer natural products. It is therefore, important to study novel mechanisms of selected cytotoxic compounds' action that could potentially represent new weapons in the fight against cancer. Though existing molecules could be chemically derivatized to expand their structural variety, all this, however rests on the hope that more and more new structures would be discovered and those having novel physiological targets or molecular mechanisms might prove most valuable. Therefore, the continued research in this field appears to hold great promise for newer therapeutic molecules to treat cancer. To date several bioactive compounds from endophytes have been identified that show anti-cancer effect [12-15,29]. Our findings suggest that this extract might prove to be a potential source of anticancer lead molecule(s). However, further work is still needed to fractionate the bioactive components for possible anticancer drug development and validation.

\section{GenBank Accession Number}

The 26S ITS-rDNA sequence of the Fusarium solani endophytic fungus described in this study has been deposited at the GenBank, NCBI under the accession number JN600625.

\section{Acknowledgements}

We thank Ms. Rekha for help in the experiments. GCK acknowledges
University Grants Commission, India for financial assistance.

\section{References}

1. Butler MS, Newman DJ (2008) Mother Nature's gifts to diseases of man: the impact of natural products on anti-infective, anticholestemics and anticancer drug discovery. Prog Drug Res 65: 1, 3-44.

2. Molinari G (2009) Natural products in drug discovery: present status and perspectives. Adv Exp Med Biol 655: 13-27.

3. Li JW, Vederas JC (2009) Drug discovery and natural products: end of an era or an endless frontier? Science 325: 161-165.

4. Daniel AD, Sylvia U, Ute R (2012) A Historical Overview of Natural Products in Drug Discovery. Metabolites 2: 303-336.

5. da Rocha AB, Lopes RM, Schwartsmann G (2001) Natural products in anticancer therapy. Curr Opin Pharmacol 1: 364-369.

6. Cragg GM, Newman DJ (2000) Antineoplastic agents from natural sources: achievements and future directions. Expert Opin Investig Drugs 9: 2783-2797.

7. Mishra BB, Tiwari VK (2011) Natural products: an evolving role in future drug discovery. Eur J Med Chem 46: 4769-4807.

8. Mondal S, Bandyopadhyay S, Ghosh MK, Mukhopadhyay S, Roy S, et al. (2012) Natural products: promising resources for cancer drug discovery. Anticancer Agents Med Chem 12: 49-75

9. Tejesvi MV, Nalini MS, Mehesh B, Prakash HS, Kini KR, et al. (2007) New hopes from endophytic secondary metabolites. Bol Soc Quim Mex 1: 19-26.

10. Farnsworth NR, Soejarto DD (1985) Potential consequences of plant extinction in the United States on the current and future availability of prescription on drugs. Econ Bot 39: 231-240.

11. Farnsworth NR, Soejarto DD (1991) Global importance of medicinal plants. In: Conservation of medicinal plants, Cambridge University Press, Cambridge: 25-51.

12. Stierle A, Strobel G, Stierle D (1993) Taxol and taxane production by Taxomyces andreanae, an endophytic fungus of Pacific yew. Science 260: 214-216.

13. Eyberger AL, Dondapati R, Porter JR (2006) Endophyte fungal isolates from Podophyllum peltatum produce podophyllotoxin. J Nat Prod 69: 1121-1124.

14. Kusari S, Zühlke S, Spiteller M (2009) An endophytic fungus from Camptotheca acuminata that produces camptothecin and analogues. J Nat Prod 72: 2-7.

15. Kumar A, Patil D, Rajamohanan PR, Ahmad A (2013) Isolation, purification and characterization of vinblastine and vincristine from endophytic fungus Fusarium oxysporum isolated from Catharanthus roseus. PLoS One 8(9):e71805.

16. Aly AH, Abdessamad D, Julia K, Peter P (2010) Fungal endophytes from higher plants: a prolific source of phytochemicals and other bioactive natural products. Fungal Diversity 41: 1-16.

17. Suryanarayanan TS, Thirunavukkarasub N, Govindarajulub MB, Sassec $F$ Jansend R, et al. (2009) Fungal endophytes and bioprospecting. Fungal Bio Rev 23: 9-19.

18. Rajesh, Sharma GL (2002) Studies on antimycotic properties of Datura metel. J Ethnopharmacol 80: 193-197.

19. Phongpaichit S, Rungjindamai N, Rukachaisirikul V, Sakayaroj J (2006) Antimicrobial activity in cultures of endophytic fungi isolated from Garcinia species. FEMS Immunol Med Microbiol 48: 367-372.

20. van de Loosdrecht AA, Beelen RH, Ossenkoppele GJ, Broekhoven MG Langenhuijsen MM (1994) A tetrazolium-based colorimetric MTT assay to quantitate human monocyte mediated cytotoxicity against leukemic cells from cell lines and patients with acute myeloid leukemia. J Immunol Methods 174 311-320.

21. Fraker PJ, King LE, Lill-Elghanian D, Telford WG (1995) Quantification of apoptotic events in pure and heterogeneous populations of cells using the flow cytometer. Methods Cell Biol 46: 57-76.

22. Cossarizza A, Baccarani-Contri M, Kalashnikova G, Franceschi C (1993) A new method for the cytofluorimetric analysis of mitochondrial membrane potential using the J-aggregate forming lipophilic cation 5,5',6,6'-tetrachloro-1,1',3,3'tetraethylbenzimidazolcarbocyanine iodide (JC-1). Biochem Biophys Res Comm 197: 40-45.

23. Lee YJ, Shacter E (1999) Oxidative stress inhibits apoptosis in human 
Citation: Kuriakose GC, Singh S, Rajvanshi PK, Surin WR, Jayabaskaran C (2014) In Vitro Cytotoxicity and Apoptosis Induction in Human Cancer Cells by Culture Extract of an Endophytic Fusarium solani Strain Isolated from Datura metel L. Pharm Anal Acta 5: 293. doi: 10.4172/21532435.1000293

Page 8 of 8

lymphoma cells. J Biol Chem 274: 19792-19798.

24. Gong J, Traganos F, Darzynkiewicz Z (1994) A selective procedure for DNA extraction from apoptotic cells applicable for gel electrophoresis and flow cytometry. Anal Biochem 218: 314-319.

25. Li H, Kolluri SK, Gu J, Dawson MI, Cao X, et al. (2000) Cytochrome c release and apoptosis induced by mitochondrial targeting of nuclear orphan receptor TR3. Science 289: 1159-1164.

26. Bortner CD, Oldenburg NB, Cidlowski JA (1995) The role of DNA fragmentation in apoptosis. Trends Cell Biol 5: 21-26.

27. Strobel G, Daisy B (2003) Bioprospecting for microbial endophytes and their natural products. Microbiol Mol Biol Rev 67: 491-502.

28. Kharwar RN, Mishra A, Gond SK, Stierle A, Stierle D (2011) Anticancer compounds derived from fungal endophytes: their importance and future challenges. Nat Prod Rep 28: 1208-1228.
29. Chakravarthi BV, Das P, Surendranath K, Karande AA, Jayabaskaran C (2008) Production of paclitaxel by Fusarium solani isolated from Taxus celebica. $J$ Biosci 33: 259-267.

30. Hao X, Jiao P, Zhu X (2013) Taxol producing fungi. In Natural Products, Ramawat K. G. and Merillon JM (eds) 2797-2812.

31. Lowe SW, Lin AW (2000) Apoptosis in cancer. Carcinogenesis 21: 485-495.

32. Kroemer G, Galluzzi L, Brenner C (2007) Mitochondrial membrane permeabilization in cell death. Physiol Rev 87: 99-163.

33. Saraste A, Pulkki K (2000) Morphologic and biochemical hallmarks of apoptosis. Cardiovasc Res 45: 528-537.

34. Schlegel RA, Williamson P (2001) Phosphatidylserine, a death knell. Cell Death Differ 8: 551-563.

35. Tounekti O, Belehradek J Jr, Mir LM (1995) Relationships between DNA fragmentation, chromatin condensation, and changes in flow cytometry profiles detected during apoptosis. Exp Cell Res 217: 506-516. 